\title{
THE
}

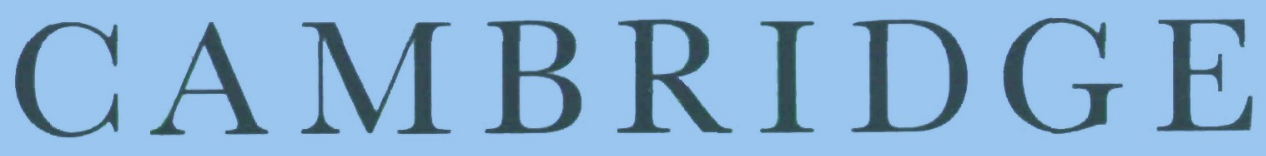

L A W

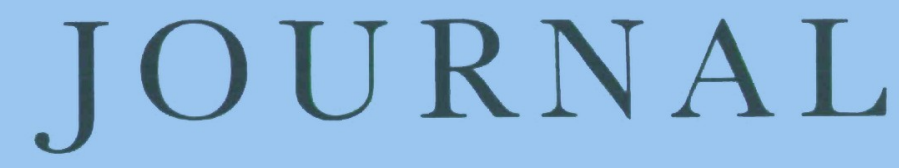

\section{July 1993}

What is a European Community Law Judge? LORD SLYNN OF HADLEY

The Unanimous Consent Rule in Company Law ROSS GRANTHAM

Governmental Liability after Francovich ROBERTO CARANTA

Pleading Involuntary Lack of Capacity

JEREMY HORDER

For full contents see back cover

\section{CAMBRIDGE UN IVERSITY PRESS}




\title{
THE CAMBRIDGE LAW JOURNAL
}

EDITORIAL COMMITTEE

\author{
C.C. Turpin, M.A., LL.B., Editor \\ M.A. Clarke, M.A., LI.B., Ph.D., Secretary and Treasurer \\ Professor J.H. Baker, LL.D., F.B.A. \\ Professor J.A. Jolowicz, M.A., Note Editor \\ Professor Sir David Williams, M.A., LL.B. \\ Professor Glanville L. Williams, Q.C., LL.D., F.B.A. \\ J.G. Collier, M.A., LL.B., Note Editor \\ C.F. Forsyth, Ph.D., Sub-editor \\ C. Harpum, M.A., LL.B., Note Editor \\ C.A. Hopkins, M.A., LL.B., Note Editor \\ C.B. Lewis, M.A., Nole Editor \\ A.V. Lowe, Ph.D., Note Editor \\ R.J.C. Munday, M.A., Ph.D., Book Review Editor \\ M.J. Prichard, M.A., LL.B. \\ P.J. Rogerson, M.A., Ph.D. \\ A.T.H. Smith, M.A., Ph.D., Note Editor \\ J.R. Spencer, M.A., LL.B., Note Editor
}

\section{SUBSCRIPTIONS 1993}

One volume of The Cambridge Law Joumal (ISSN 0008-1973) is published each year. Each volume is in three parts, published in March, July and November. The subscription price of Volume 52 is $£ 32.00$ net (US\$72.00 in the USA, Canada and Mexico), including postage, and is payable in advance. Reduced rate subscriptions are available to members of the Society of Public Teachers of Law and the Association of Law Teachers, law students and recently qualified lawyers. Details may be obtained from the publishers. Single parts cost $£ 12.00$ net (US $\$ 25.00$ in the USA, Canada and Mexico) plus postage. Orders may be sent to any bookseller or subscription agent or to Cambridge University Press, The Edinburgh Building, Shaftesbury Road, Cambridge CB2 2RU, or in the USA, Canada and Mexico to Cambridge University Press, The Journals Department, 40 West 20th Street, New York, NY 10011-4211. Japanese prices for institutions (including ASP delivery) are available from Kinokuniya Company Ltd., P.O. Box 55, Chitose, Tokyo.

(C) The Cambridge Law Journal and Contributors, 1993

BACK VOLUMES

All back volumes are kept in print hardbound and may be purchased at the prices shown below. A discount of $10 \%$ is given on a single order for 25 or more volumes.

Vols. 1-11 (1921-1953)

one volume of 3 parts every 3 years

$£ 35.00, \$ 72.00$ per volume

Vols. 12-30 (1954-1972)

one volume of 2 parts every year $\quad £ 32 \cdot 00, \$ 72.00$ per volume

Vol. 31 (1972) Jubilee Issue

including Index 1921-1970

$£ 32 \cdot 00, \$ 72 \cdot 00$ per volume

Vols. 32-43 (1973-1984)

one volume of 2 parts every year $\quad £ 32 \cdot 00, \$ 72.00$ per volume

Vols. 44-51 (1985-1992)

one volume of 3 parts every year

$£ 32 \cdot 00, \$ 72 \cdot 00$ per volume

The cumulative index $1921-1991$ is also available separately at $£ 12.00(\$ 25.00$ in the USA, Canada and Mexico). 